\title{
PENERAPAN SISTEM ANTRIAN SEBAGAI UPAYA PENGOPTIMALKAN PELAYANAN TERHADAP PASIEN PADA LOKET PENGAMBILAN OBAT DI RSI. IBNU SINA PASAMAN BARAT DENGAN MENGGUNAKAN METODE MONTE CARLO
}

\author{
Novi Trisna ${ }^{1}$, Wifra Safitri ${ }^{2}$, Mutia Pratiwi ${ }^{3}$ \\ Universitas Putra Indonesia "YPTK” Padang
}

\begin{abstract}
Queue is an activity that is often encountered not only in commercial activities, even RSI. Ibnu Sina Pasaman Barat engaged in services for the community also experienced the same thing. This needs to be considered and handled properly by the manager by taking anticipatory actions, because if it is not immediately resolved, then the community can feel unsatisfied with the services provided. Related to these problems, this study was conducted with the aim to determine the effectiveness of the number of counters at the time of service and make a simulation model of the drug collection queue system at the RSI drug collection counter. Ibnu Sina Pasaman Barat to get alternative system improvements, where the simulation model was made using PHP and MySQL. The simulation model made can provide information about the number of people served and the average waiting time of a particular time unit. From the analysis carried out on the simulation model, the alternative improvements that can be proposed are by setting the Monte Carlo method queue model as the queue model that will be used. From the results of the analysis carried out and by implementing it into PHP and MySQL the queue model of the Monte Carlo method is more optimal and efficient. It is seen from the average waiting time in the system to be served at the RSI drug collection counter. Ibnu Sina Pasaman Barat.
\end{abstract}

Keywords - Queues, Simulation, Monte Carlo

Abstrak - Antrian merupakan kegiatan yang kerap kali dijumpai bukan hanya pada kegiatan-kegiatan komersial, bahkan RSI. Ibnu Sina Pasaman Barat yang bergerak dibidang pelayanan bagi masyarakat juga mengalami hal yang sama. Hal ini perlu diperhatikan dan ditangani dengan baik oleh pengelola dengan melakukan tindakan-tindakan antisipasi, karena jika tidak segera terselesaikan, maka masyarakat bisa merasa tidak terpuaskan dengan pelayanan yang diberikan. Terkait dengan permasalahan tersebut maka penelitian ini dilakukan dengan tujuan untuk mengetahui keefektifitas jumlah loket pada saat pelayanan dan membuat model simulasi dari sistem antrian pengambilan obat di loket pengambilan obat RSI. Ibnu Sina Pasaman Barat untuk mendapatkan alternatif-alternatif perbaikan sistem, dimana model simulasinya dibuat dengan menggunakan PHP dan MySQL.Model simulasi yang dibuat dapat memberikan informasi mengenai jumlah masyarakat yang dilayani dan rata-rata waktu tunggu masyarakat satuan waktu tertentu. Dari analisa yang dilakukan terhadap model simulasi, alternatif perbaikan yang dapat diusulkan yaitu dengan menetapkan model antrian metode monte carlo sebagai model antrian yaang akan digunakan. Dari hasil analisa yang dilakukan dan dengan mengimplementasikan kedalam PHP dan MySQL model antrian metode monte carlo lebih optimal dan efisien digunakan dilihat dari rata-rata waktu tunggu dalam sistem untuk dilayani pada loket pengambilan obat RSI. Ibnu Sina Pasaman Barat.

Kata Kunci - Antrian, Simulasi, Monte Carlo

\section{PENDAHULUAN}

\section{A. Latar Belakang}

Antrian merupakan kejadian yang sering kita temui di berbagai tempat yang memberikan pelayanan kepada masyarakat, diantaranya rumah sakit, bank, jalan tol dan lainnya. Pelayanan terhadap kepuasan konsumen merupakan suatu hal yang sangat penting, sehingga peningkatan kualitas terhadap pelayanan konsumen harus selalu dilakukan. Sistem antrian yang baik akan berpengaruh terhadap perilaku dan kepuasan konsumen. Antrian adalah keadaan menunggu untuk mendapatkan giliran. Umumnya antrian terbentuk jika banyaknya pelanggan yang akan dilayani melebihi kapasitas yang tersedia, sehingga menyebabkan para pelanggan yang datang tidak bisa langsung untuk dilayani. Dalam hal ini kepuasan pelanggan merupakan menjadi yang utama.
Rumah Sakit Islam Ibnu Sina Simpang Ampek merupakan rumah sakit yang pertama berada di Kabupaten Pasaman Barat. Antrian pada rumah sakit ini terjadi pada loket pengambilan obat terutama pada jam-jam sibuk yang dimana banyaknya pelanggan yang akan dilayani melebihi kapasitas yang tersedia, sehingga menyebabkan para pelanggan yang datang tidak bisa langsung untuk dilayani sehingga menjadi permasalahan yang menyebabkan kurang efektifnya pelayanan yang terjadi di rumah sakit tersebut. Permasalahan yang terjadi adalah bagaiman cara mengurangi antrian serta meningkatkan pelayanan agar pasien tidak menunggu terlalu lama yang diakibatkan penumpukan antrian tersebut.

Berdasarkan kondisi diatas, penulis tertarik melakukan penelitian dan membahas dalam bentuk tugas akhir skripsi dengan judul : "Penerapan Sistem Antrian Sebagai Upaya Pengoptimalkan Pelayanan Terhadap Pasien Pada Loket Pengambilan Obat Di 
Rsi. Ibnu Sina Pasaman Barat dengan Menggunakan Metode Monte Carlo"

\section{A. Model dan Simulasi}

\section{TINJAUAN PUSTAKA}

Model didefinisikan sebagai suatu perwakilan atau abstraksi dari sebuah objek atau situasi aktual.Model memperlihatkan hubungan-hubungan langsung maupun tidak langsung serta kaitan timbal balik dalam istilah sebab akibat. Sedangkan Simulasi merupakan suatu alat analisis yang handal untuk merencanakan, mendesain, dan mengontrol proses sistem yang kompleks.[1]

Model simulasi sistem dikelompokkan ke dalam 3 dimensi berikut:

1.Statik dan Dinamik. Pada model statik, waktu tidak memiliki peranan terhadap karakteristik sistem. Tetapi pada model dinamik, waktu memiliki peranan yang penting. Sebagian besar model operasional merupakan model dinamik.

2.Kontinyu dan Diskrit. Model simulasi kontinyu melibatkan persamaan diferensial (turunan) yang menyatakan bentuk laju perubahan variabel kondisi terhadap waktu. Model simulasi diskrit dapat dikerjakan dengan perhitungan manual, jika hanya melibatkan sedikit kumpulan data yang diolah.

3.Deterministik dan Stokastik. Model simulasi deterministik output (hasil) ditentukan oleh sekumpulan (set) kuantitas input dan hubungan dalam model yang telah ditentukan. Model simulasi stokastik output (hasil) yang diperoleh bersifat random, dan harus diperlakukan sebagai estimasi karakteristik model yang benar. Inilah kekurangan dari model simulasi. [2]

\section{B. Antrian}

Ada empat bentuk disiplin antrian pelayanan yang biasa digunakan dalam praktek, yaitu:

1.First In First Out (FIFO) yang artinya adalah yang lebih dahulu datang (tiba) yang lebih dulu dilayani.

2.Last In First Out (LIFO) yang artinya adalah yang tiba terakhir yang lebih dulu keluar.

3.Service In Random Order (SIRO) yang artinya adalah pemanggilan didasarkan pada peluang secara random, tidak menjadi persoalan siapa yang lebih dulu tiba.

4.Priority Service (PS) yang artinya, prioritas pelayanan. [3]

\section{Metode Monte Carlo}

Metode monte carlo adalah algoritma koputasi untuk mensimulasikan berbagai prilaku sistem fisika dan matematika. Metode Monte Carlo sangat penting dalam fisika komputasi dan bidang terapan lainnya, dan memiliki aplikasi yang beragam mulai dari penghitungan kromodinamika kuantum esoterik hingga perancangan aerodinamika. Metode ini terbukti efesien dalam memecahkan persamaan diferensial integral medan radians, sehingga metodeini digunakan dalam penghitungan dimensi yang diterapkan dalam video games, arsitektur, perancangan, bisnis ekonomi dan lainnya. Penggunaan metode Monte Carlo memerlukan sejumlah besar bilangan acak, dan hal tersebut semakin mudah dengan perkembangan pembangkit bilangan acak, yang jauh lebih cepat dan praktis dibanding dengan metode sebelumnya. [4]

Dalam melakukan simulasi menggunakan metode monte carlo, diperlukan beberapa bilangan acak untuk menentukan interval selisih waktu kedatangan dan interval waktu pelayanan pelanggan. Pembentukan bilangan acak dilakukan dengan metode LCM (Linear Congruent Method).[5]

Proses pembentukan bilangan acak didasari suatu rumus seperti berikut :

Rumus LCM : Xi+1 $=(\mathrm{a} \mathrm{Xi}+1+\mathrm{C}) \bmod \mathrm{M}$

Keterangan :

$\begin{array}{ll}\mathrm{Xi} & \text { : Nilai awal yang ditentukan } \\ \mathrm{A} & \text { : Konstanta Perkalian } \\ \mathrm{C} & \text { : Kenaikan } \\ \mathrm{Mod} & \text { : Modulus } \\ \mathrm{M} & \text { : Bilangan Tetap }\end{array}$

\section{ANALISA DAN PERANCANGAN}

\section{A. Analisa Sistem}

Analisa sistem dilakukan bertujuan untuk mengetahui kelemahan-kelemahan yang terjadi pada sistem yang sedang berjalan (sistem lama). Dengan dilakukannya analisa terhadap sistem lama nantinya akan dapat dijadikan sebagai perbandingan, pengoreksian serta perancangan kearah sistem yang baru.

Jenis sistem antrian yang diberlakukan di RSI. Ibnu Sina Pasaman Barat adalah jenis sistem antrian dengan menggunakan metode monte carlo, dimana sistem antrian dengan alur pelayanan untuk melayani setiap pasien bersifat random (acak).

\section{B. Pengumpulan Data}

Dari pengumpulan data di lapangan maka diperoleh waktu kedatangan, mulai proses dan selesai diproses pada RSI. Ibnu Sina Pasaman Barat, yang dapat dilihat pada tabel 3.1.

Tabel 3.1 Data Mentah Antrian Loket Pengambilan Obat RSI. Ibnu Sina Pasaman Barat

\begin{tabular}{|c|c|c|c|}
\hline NO & AT & SST & SET \\
1 & 7.55 & 8.10 & 8.15 \\
\hline 2 & 8.07 & 8.15 & 8.17 \\
\hline 3 & 8.12 & 8.17 & 8.22 \\
\hline 4 & 8.22 & 8.22 & 8.27 \\
\hline
\end{tabular}




\begin{tabular}{|c|c|c|c|}
\hline $\mathrm{NO}$ & $\mathrm{AT}$ & SST & SET \\
\hline 5 & 8.25 & 8.27 & 8.32 \\
\hline 6 & 8.28 & 8.32 & 8.35 \\
\hline 7 & 8.32 & 8.35 & 8.40 \\
\hline 8 & 8.40 & 8.40 & 8.45 \\
\hline 9 & 8.43 & 8.45 & 8.50 \\
\hline 10 & 8.48 & 8.50 & 8.55 \\
\hline 11 & 8.52 & 8.55 & 8.57 \\
\hline 12 & 8.56 & 8.57 & 9.00 \\
\hline 13 & 8.59 & 9.00 & 9.05 \\
\hline 14 & 9.02 & 9.05 & 9.10 \\
\hline 15 & 9.08 & 9.10 & 9.15 \\
\hline 16 & 9.12 & 9.15 & 9.20 \\
\hline 17 & 9.20 & 9.20 & 9.24 \\
\hline 18 & 9.23 & 9.24 & 9.29 \\
\hline 19 & 9.27 & 9.29 & 9.34 \\
\hline 20 & 9.30 & 9.34 & 9.36 \\
\hline 21 & 9.33 & 9.36 & 9.40 \\
\hline 22 & 9.39 & 9.40 & 9.45 \\
\hline 23 & 9.42 & 9.45 & 9.50 \\
\hline 24 & 9.45 & 9.50 & 9.55 \\
\hline 25 & 9.48 & 9.55 & 10.00 \\
\hline 26 & 9.51 & 10.00 & 10.05 \\
\hline 27 & 9.55 & 10.05 & 10.10 \\
\hline 28 & 10.00 & 10.10 & 10.15 \\
\hline 29 & 10.03 & 10.15 & 10.20 \\
\hline 30 & 10.15 & 10.20 & 10.25 \\
\hline 31 & 10.22 & 10.25 & 10.30 \\
\hline 32 & 10.30 & 10.30 & 10.35 \\
\hline 33 & 10.33 & 10.35 & 10.39 \\
\hline 34 & 10.38 & 10.39 & 10.44 \\
\hline 35 & 10.44 & 10.44 & 10.49 \\
\hline 36 & 10.47 & 10.49 & 10.52 \\
\hline 37 & 10.50 & 10.52 & 10.57 \\
\hline 38 & 10.55 & 10.57 & 11.02 \\
\hline 39 & 11.59 & 11.02 & 11.07 \\
\hline
\end{tabular}

\begin{tabular}{|c|c|c|c|}
\hline $\mathrm{NO}$ & $\mathrm{AT}$ & SST & SET \\
\hline 40 & 11.03 & 11.07 & 11.12 \\
\hline 41 & 11.12 & 11.12 & 11.17 \\
\hline 42 & 11.15 & 11.17 & 11.22 \\
\hline 43 & 11.18 & 11.22 & 11.25 \\
\hline 44 & 11.21 & 11.25 & 11.30 \\
\hline 45 & 11.25 & 11.30 & 11.35 \\
\hline 46 & 11.33 & 11.35 & 11.40 \\
\hline 47 & 11.39 & 11.40 & 11.45 \\
\hline 48 & 11.42 & 11.45 & 11.49 \\
\hline 49 & 11.48 & 11.49 & 11.54 \\
\hline 50 & 11.52 & 11.54 & 11.59 \\
\hline 51 & 11.57 & 11.59 & 12.04 \\
\hline 52 & 12.00 & 12.04 & 12.07 \\
\hline 53 & 12.12 & 13.15 & 13.18 \\
\hline 54 & 13.00 & 13.18 & 13.20 \\
\hline 55 & 13.03 & 13.20 & 13.25 \\
\hline 56 & 13.10 & 13.25 & 13.29 \\
\hline 57 & 13.17 & 13.29 & 13.31 \\
\hline 58 & 13.24 & 13.31 & 13.36 \\
\hline 59 & 13.32 & 13.36 & 13.40 \\
\hline 60 & 13.36 & 13.40 & 14.45 \\
\hline 61 & 13.41 & 14.45 & 13.49 \\
\hline 62 & 13.45 & 13.49 & 13.54 \\
\hline 63 & 13.50 & 13.54 & 13.59 \\
\hline 64 & 13.59 & 13.59 & 14.04 \\
\hline 65 & 14.03 & 14.04 & 14.09 \\
\hline 66 & 14.08 & 14.09 & 14.14 \\
\hline 67 & 14.12 & 14.14 & 14.18 \\
\hline 68 & 14.16 & 14.18 & 14.23 \\
\hline 69 & 14.20 & 14.23 & 14.28 \\
\hline 70 & 14.26 & 14.28 & 14.32 \\
\hline 71 & 14.31 & 14.32 & 14.37 \\
\hline 72 & 14.36 & 14.37 & 14.42 \\
\hline 73 & 14.41 & 14.42 & 14.47 \\
\hline 74 & 14.46 & 14.47 & 14.52 \\
\hline
\end{tabular}




\begin{tabular}{|c|c|c|c|}
\hline NO & AT & SST & SET \\
75 & 14.50 & 14.52 & 14.56 \\
\hline 76 & 14.55 & 14.56 & 15.01 \\
\hline 77 & 14.59 & 15.01 & 15.05 \\
\hline 78 & 15.05 & 15.05 & 15.10 \\
\hline 79 & 15.10 & 15.10 & 15.14 \\
\hline 80 & 15.13 & 15.14 & 15.16 \\
\hline
\end{tabular}

Keterangan :

AT : Arrival Time (Waktu Datang)

SST : Service Start Time (Mulai Pelayanan)

SET : Service End Time (Selesai Pelayanan)

Dari pengumpulan data tersebut dapat diolah lagi untuk mencari waktu dalam antrian dan waktu dalam sistem seperti yang dapat dilihat pada tabel 3.2 berikut:

Tabel 3.2 Waktu Dalam Antrian Dan Waktu Dalam Sistem

\begin{tabular}{|c|c|c|c|c|c|c|}
\hline $\begin{array}{c}\text { N } \\
\text { O }\end{array}$ & AT & SST & SET & ST & $\begin{array}{c}\text { TI } \\
\text { Q }\end{array}$ & $\begin{array}{c}\text { TI } \\
\text { S }\end{array}$ \\
\hline 1 & 7.55 & 7.55 & 8.00 & 5 & 0 & 5 \\
\hline 2 & 8.07 & 8.07 & 8.12 & 5 & 0 & 5 \\
\hline 3 & 8.12 & 8.12 & 8.17 & 5 & 0 & 5 \\
\hline 4 & 8.22 & 8.22 & 8.27 & 5 & 0 & 5 \\
\hline 5 & 8.25 & 8.27 & 8.32 & 5 & 2 & 7 \\
\hline 6 & 8.28 & 8.32 & 8.35 & 3 & 4 & 7 \\
\hline 7 & 8.32 & 8.35 & 8.40 & 5 & 3 & 8 \\
\hline 8 & 8.40 & 8.40 & 8.45 & 5 & 0 & 5 \\
\hline 9 & 8.43 & 8.45 & 8.50 & 5 & 2 & 7 \\
\hline 10 & 8.48 & 8.50 & 8.55 & 5 & 2 & 7 \\
\hline 11 & 8.52 & 8.55 & 8.57 & 2 & 3 & 5 \\
\hline 12 & 8.56 & 8.57 & 9.00 & 3 & 1 & 4 \\
\hline 13 & 8.59 & 9.00 & 9.05 & 5 & 1 & 6 \\
\hline 14 & 9.02 & 9.05 & 9.10 & 5 & 3 & 8 \\
\hline 15 & 9.08 & 9.10 & 9.15 & 5 & 2 & 7 \\
\hline 16 & 9.12 & 9.15 & 9.20 & 5 & 3 & 8 \\
\hline 17 & 9.20 & 9.20 & 9.24 & 4 & 0 & 4 \\
\hline 18 & 9.23 & 9.24 & 9.29 & 5 & 1 & 6 \\
\hline 19 & 9.27 & 9.29 & 9.34 & 5 & 2 & 7 \\
\hline 20 & 9.30 & 9.34 & 9.36 & 2 & 4 & 6 \\
\hline 21 & 9.33 & 9.36 & 9.40 & 4 & 3 & 7 \\
\hline
\end{tabular}

\begin{tabular}{|c|c|c|c|c|c|c|}
\hline $\begin{array}{l}\mathrm{N} \\
\mathrm{O}\end{array}$ & $\mathrm{AT}$ & SST & SET & ST & $\begin{array}{l}\mathrm{TI} \\
\mathrm{Q}\end{array}$ & $\begin{array}{l}\mathrm{TI} \\
\mathrm{S}\end{array}$ \\
\hline 22 & 9.39 & 9.40 & 9.45 & 5 & 1 & 6 \\
\hline 23 & 9.42 & 9.45 & 9.50 & 5 & 3 & 8 \\
\hline 24 & 9.45 & 9.50 & 9.55 & 5 & 5 & 10 \\
\hline 25 & 9.48 & 9.55 & 10.00 & 5 & 7 & 12 \\
\hline 26 & 9.51 & 10.00 & 10.05 & 5 & 9 & 14 \\
\hline 27 & 9.55 & 10.05 & 10.10 & 5 & 10 & 15 \\
\hline 28 & 10.00 & 10.10 & 10.15 & 5 & 10 & 15 \\
\hline 29 & 10.03 & 10.15 & 10.20 & 5 & 12 & 17 \\
\hline 30 & 10.15 & 10.20 & 10.25 & 5 & 5 & 10 \\
\hline 31 & 10.22 & 10.25 & 10.30 & 5 & 3 & 8 \\
\hline 32 & 10.30 & 10.30 & 10.35 & 5 & 0 & 5 \\
\hline 33 & 10.33 & 10.35 & 10.39 & 4 & 2 & 6 \\
\hline 34 & 10.38 & 10.39 & 10.44 & 5 & 1 & 6 \\
\hline 35 & 10.44 & 10.44 & 10.49 & 5 & 0 & 5 \\
\hline 36 & 10.47 & 10.49 & 10.52 & 3 & 2 & 5 \\
\hline 37 & 10.50 & 10.52 & 10.57 & 5 & 2 & 7 \\
\hline 38 & 10.55 & 10.57 & 11.02 & 5 & 2 & 7 \\
\hline 39 & 11.59 & 11.02 & 11.07 & 5 & 3 & 8 \\
\hline 40 & 11.03 & 11.07 & 11.12 & 5 & 4 & 9 \\
\hline 41 & 11.12 & 11.12 & 11.17 & 5 & 0 & 5 \\
\hline 42 & 11.15 & 11.17 & 11.22 & 5 & 2 & 7 \\
\hline 43 & 11.18 & 11.22 & 11.25 & 3 & 4 & 7 \\
\hline 44 & 11.21 & 11.25 & 11.30 & 5 & 4 & 9 \\
\hline 45 & 11.25 & 11.30 & 11.35 & 5 & 5 & 10 \\
\hline 46 & 11.33 & 11.35 & 11.40 & 5 & 2 & 7 \\
\hline 47 & 11.39 & 11.40 & 11.45 & 5 & 1 & 6 \\
\hline 48 & 11.42 & 11.45 & 11.49 & 4 & 3 & 7 \\
\hline 49 & 11.48 & 11.49 & 11.54 & 5 & 1 & 6 \\
\hline 50 & 11.52 & 11.54 & 11.59 & 5 & 2 & 7 \\
\hline 51 & 11.57 & 11.59 & 12.04 & 5 & 2 & 7 \\
\hline 52 & 12.00 & 12.04 & 12.07 & 3 & 4 & 7 \\
\hline 53 & 12.12 & 13.15 & 13.18 & 3 & 3 & 6 \\
\hline 54 & 13.00 & 13.18 & 13.20 & 2 & 18 & 20 \\
\hline 55 & 13.03 & 13.20 & 13.25 & 5 & 17 & 22 \\
\hline
\end{tabular}




\begin{tabular}{|c|c|c|c|c|c|c|}
\hline $\begin{array}{l}\text { N } \\
\text { O }\end{array}$ & AT & SST & SET & ST & $\begin{array}{c}\text { TI } \\
\text { Q }\end{array}$ & $\begin{array}{c}\text { TI } \\
\text { S }\end{array}$ \\
\hline 56 & 13.10 & 13.25 & 13.29 & 4 & 15 & 19 \\
\hline 57 & 13.17 & 13.29 & 13.31 & 2 & 12 & 14 \\
\hline 58 & 13.24 & 13.31 & 13.36 & 5 & 6 & 11 \\
\hline 59 & 13.32 & 13.36 & 13.40 & 4 & 4 & 8 \\
\hline 60 & 13.36 & 13.40 & 14.45 & 5 & 4 & 9 \\
\hline 61 & 13.41 & 14.45 & 13.49 & 4 & 4 & 8 \\
\hline 62 & 13.45 & 13.49 & 13.54 & 5 & 4 & 9 \\
\hline 63 & 13.50 & 13.54 & 13.59 & 5 & 4 & 9 \\
\hline 64 & 13.59 & 13.59 & 14.04 & 5 & 0 & 5 \\
\hline 65 & 14.03 & 14.04 & 14.09 & 5 & 1 & 6 \\
\hline 66 & 14.08 & 14.09 & 14.14 & 5 & 1 & 6 \\
\hline 67 & 14.12 & 14.14 & 14.18 & 4 & 2 & 6 \\
\hline 68 & 14.16 & 14.18 & 14.23 & 5 & 2 & 7 \\
\hline 69 & 14.20 & 14.23 & 14.28 & 5 & 3 & 8 \\
\hline 70 & 14.26 & 14.28 & 14.32 & 4 & 2 & 6 \\
\hline 71 & 14.31 & 14.32 & 14.37 & 5 & 1 & 6 \\
\hline 72 & 14.36 & 14.37 & 14.42 & 5 & 1 & 6 \\
\hline 73 & 14.41 & 14.42 & 14.47 & 5 & 1 & 6 \\
\hline 74 & 14.46 & 14.47 & 14.52 & 5 & 1 & 6 \\
\hline 75 & 14.50 & 14.52 & 14.56 & 4 & 2 & 6 \\
\hline 76 & 14.55 & 14.56 & 15.01 & 5 & 1 & 6 \\
\hline 77 & 14.59 & 15.01 & 15.05 & 4 & 2 & 6 \\
\hline 78 & 15.05 & 15.05 & 15.10 & 5 & 0 & 5 \\
\hline 79 & 15.10 & 15.10 & 15.14 & 4 & 0 & 4 \\
\hline 80 & 15.13 & 15.14 & 15.16 & 2 & 1 & 3 \\
\hline & & & & & 25 & 62 \\
\hline $6 \mathrm{NMLAH}-\mathrm{RATA}$ & & & 24 & 75 \\
\hline
\end{tabular}

Keterangan :

AT : Arrival Time (waktu datang)

SST : Service Start Time (mulai pelayanan)

SET : Service End Time (selesai pelayanan)

TIQ : Time In Queue (waktu di antrian)

TIS : Time In System (waktu dalam sistem)

ST : Service Time (waktu pelayanan)

Hasil dari simulasi antrian nyata dapat dilihat pada tabel 3.3 Karakteristik Operasi Hasil Simulasi:

Tabel 3.3 Karakteristik Operasi Hasil Simulasi

\begin{tabular}{|c|c|c|l|}
\hline \multirow{4}{*}{ Informasi } & $\begin{array}{c}\text { Rata-rata waktu } \\
\text { menunggu }\end{array}$ & $\begin{array}{c}277 / \\
80=\end{array}$ & \multirow{2}{*}{ Menit } \\
& $\begin{array}{c}\text { customer } \\
\text { diantrian }\end{array}$ & 3.50 & \\
\cline { 2 - 4 } & Rata-rata waktu & $645 /$ & \\
& customers & $80=$ & Menit \\
& disistem & 8,06 & \\
\hline
\end{tabular}

\section{Analisa Proses}

Pada analisa proses ini yang dicontohkan hanya 30 data antrian yang akan diolah menggunakan metode monte carlo.

Ilustrasi simulasi sebagai berikut :

1. Data Input

Data yang akan diolah pada tabel 3.4: Tabel 3.4 Data Input

\begin{tabular}{|c|c|}
\hline Input & Waktu/orang \\
\hline Jumlah Pasien & 80 orang \\
\hline Waktu Kedatangan & $3-12$ menit \\
\hline Waktu Pelayanan & $2-5$ menit \\
\hline & \\
\hline
\end{tabular}

2. Interval

Interval waktu selisih kedatangan didapatkan dari pembagian banyak bilangan random dibagi banyak interval Pembagian random $=$

$\frac{\text { banyak bilangan random }}{\text { banyak interval }}=\frac{100}{10}=10$ nilai Interval yang dapat dilihat pada Tabel 3.5 berikut :

Tabel 3.5 Inputan Interval Waktu Selisih Kedatangan

\begin{tabular}{|c|c|}
\hline $\begin{array}{c}\text { Interval Waktu } \\
\text { Kedatangan }\end{array}$ & Bilangan Acak \\
\hline 3 & $1-9$ \\
\hline 4 & $10-19$ \\
\hline 5 & $20-29$ \\
\hline 6 & $30-39$ \\
\hline 7 & $40-49$ \\
\hline 8 & $50-59$ \\
\hline 9 & $60-69$ \\
\hline 10 & $70-79$ \\
\hline 11 & $80-89$ \\
\hline 12 & $90-99$ \\
\hline
\end{tabular}

Interval mulai dari 4 menit karena kedatangan pada masyarakat dimulai dari 4 (empat) dengan selisih waktu kedatangannya 15 menit.

Interval waktu pelayanan didapatkan dari

Pembagian random $=\frac{\text { banyak bilangan random }}{\text { banyak interval }}=$ $\frac{100}{4}=25$ nilai

Inputan interval waktu pelayanan dapat dilihat pada tabel 3.6 berikut:

Tabel 3.6 Inputan Interval Waktu Pelayanan 


\begin{tabular}{|c|c|}
\hline $\begin{array}{c}\text { Interval Waktu } \\
\text { Pelayanan }\end{array}$ & Bilangan Acak \\
\hline 2 & $1-24$ \\
\hline 3 & $25-49$ \\
\hline 4 & $50-74$ \\
\hline 5 & $75-99$ \\
\hline
\end{tabular}

Menentukan angka random yang digunakan untuk mendapatkan nilai selisih waktu kedatangan dengan nilai waktu pelayanan dilakukan dengan rumus LCM (Linear Congruent Method). Penarikan angka random untuk mendapatkan nilai IAT dengan menggunakan simulasi ini adalah sebagai berikut :

Rumus $\mathrm{LCM}=\mathrm{X}_{\mathrm{i}+1}=\left(\mathrm{a} \mathrm{X}_{\mathrm{i}+1}+\mathrm{C}\right) \bmod \mathrm{M}$ Dimana :

a : Konstanta Perkalian

$\mathrm{Xi}$ : Nilai awal yang ditentukan

C : Kenaikan

M : Bilangan Tetap

$\mathrm{a}=17 \quad \mathrm{Xi}=35 \quad \mathrm{C}=43$

$M=100$

Menentukan angka random yang digunakan untuk mendapatkan nilai waktu pelayanan dengan menggunakan simulasi ini adalah sebagai berikut :

Rumus LCM $=X_{i+1}=\left(a X_{i+1}+C\right) \bmod M$

$$
\mathrm{a}=38 \quad \mathrm{Xi}=19 \quad \mathrm{C}=41 \quad \mathrm{M}=100
$$

Setelah didapatkan bilangan random melalui rumus LCM (Linear Congruent Method) maka dilakukan ilustrasi dengan simulasi metode monte carlo seperti pada tabel 3.9 berikut:

Tabel 3.9 Ilustrasi Simulasi Metode Monte Carlo

\begin{tabular}{|c|c|c|c|c|c|c|c|c|c|}
\hline 号 & RN & IAT & AT & SST & RN & $\begin{array}{c}\text { S } \\
\text { T }\end{array}$ & SET & $\begin{array}{c}\text { TI } \\
\text { Q }\end{array}$ & $\begin{array}{c}\text { TI } \\
\text { S }\end{array}$ \\
\hline 1 & 38 & 6 & 7.55 & 8.01 & 63 & 4 & 8.05 & 6 & 10 \\
\hline 2 & 89 & 11 & 8.07 & 8.07 & 35 & 3 & 8.10 & 0 & 3 \\
\hline 3 & 56 & 8 & 8.12 & 8.12 & 71 & 4 & 8.16 & 0 & 4 \\
\hline 4 & 95 & 12 & 8.22 & 8.22 & 39 & 3 & 8.25 & 0 & 3 \\
\hline 5 & 58 & 8 & 8.25 & 8.25 & 23 & 2 & 8.27 & 0 & 2 \\
\hline 6 & 29 & 5 & 8.28 & 8.28 & 15 & 2 & 8.30 & 0 & 2 \\
\hline 7 & 36 & 6 & 8.32 & 8.32 & 11 & 2 & 8.34 & 0 & 2 \\
\hline 8 & 55 & 8 & 8.40 & 8.40 & 59 & 4 & 8.44 & 0 & 4 \\
\hline 9 & 78 & 10 & 8.43 & 8.44 & 83 & 5 & 8.49 & 1 & 6 \\
\hline 10 & 69 & 9 & 8.48 & 8.49 & 95 & 5 & 8.54 & 1 & 6 \\
\hline 11 & 16 & 4 & 8.52 & 8.54 & 51 & 4 & 8.56 & 2 & 4 \\
\hline 12 & 15 & 4 & 8.56 & 8.56 & 79 & 5 & 9.01 & 0 & 5 \\
\hline 13 & 98 & 12 & 8.59 & 9.01 & 43 & 3 & 9.04 & 2 & 5 \\
\hline 14 & 9 & 3 & 9.02 & 9.04 & 75 & 4 & 9.08 & 2 & 6 \\
\hline 15 & 96 & 12 & 9.08 & 9.08 & 91 & 5 & 9.13 & 0 & 5 \\
\hline 16 & 75 & 10 & 9.12 & 9.13 & 99 & 5 & 9.18 & 1 & 6 \\
\hline
\end{tabular}

\begin{tabular}{|c|c|c|c|c|c|c|c|c|c|}
\hline$\frac{\mathscr{O}}{3}$ & RN & IAT & $\mathrm{AT}$ & SST & RN & $\begin{array}{l}\mathrm{S} \\
\mathrm{T}\end{array}$ & SET & $\begin{array}{l}\mathrm{TI} \\
\mathrm{Q}\end{array}$ & $\begin{array}{l}\text { TI } \\
\text { S }\end{array}$ \\
\hline 17 & 18 & 4 & 9.20 & 9.20 & 3 & 2 & 9.22 & 0 & 2 \\
\hline 18 & 49 & 7 & 9.23 & 9.23 & 55 & 4 & 9.27 & 0 & 4 \\
\hline 19 & 76 & 10 & 9.27 & 9.27 & 31 & 3 & 9.30 & 0 & 3 \\
\hline 20 & 35 & 6 & 9.30 & 9.30 & 19 & 2 & 9.32 & 0 & 2 \\
\hline 21 & 38 & 6 & 9.33 & 9.33 & 63 & 4 & 9.37 & 0 & 4 \\
\hline 22 & 89 & 11 & 9.39 & 9.39 & 35 & 3 & 9.42 & 0 & 3 \\
\hline 23 & 56 & 8 & 9.42 & 9.42 & 71 & 4 & 9.46 & 0 & 4 \\
\hline 24 & 95 & 12 & 9.45 & 9.46 & 39 & 3 & 9.49 & 1 & 4 \\
\hline 25 & 58 & 8 & 9.48 & 9.49 & 23 & 2 & 9.51 & 1 & 3 \\
\hline 26 & 29 & 5 & 9.51 & 9.51 & 15 & 2 & 9.53 & 0 & 2 \\
\hline 27 & 36 & 6 & 9.55 & 9.55 & 11 & 2 & 9.57 & 0 & 2 \\
\hline 28 & 55 & 8 & 10.00 & $\begin{array}{c}10.0 \\
0 \\
\end{array}$ & 59 & 4 & $\begin{array}{c}10.0 \\
4 \\
\end{array}$ & 0 & 4 \\
\hline 29 & 78 & 10 & 10.03 & $\begin{array}{c}10.0 \\
4 \\
\end{array}$ & 83 & 5 & $\begin{array}{c}10.0 \\
9 \\
\end{array}$ & 1 & 6 \\
\hline 30 & 69 & 9 & 10.15 & $\begin{array}{c}10.1 \\
5\end{array}$ & 95 & 5 & $\begin{array}{c}10.2 \\
0\end{array}$ & 0 & 5 \\
\hline 31 & 16 & 4 & 10.22 & $\begin{array}{c}10.2 \\
2 \\
\end{array}$ & 51 & 4 & $\begin{array}{c}10.2 \\
4 \\
\end{array}$ & 0 & 2 \\
\hline 32 & 15 & 4 & 10.30 & $\begin{array}{c}10.3 \\
0 \\
\end{array}$ & 79 & 5 & $\begin{array}{c}10.3 \\
5 \\
\end{array}$ & 0 & 5 \\
\hline 33 & 98 & 12 & 10.33 & $\begin{array}{c}10.3 \\
5 \\
\end{array}$ & 43 & 3 & $\begin{array}{c}10.3 \\
8 \\
\end{array}$ & 2 & 5 \\
\hline 34 & 9 & 3 & 10.38 & $\begin{array}{c}10.3 \\
8\end{array}$ & 75 & 4 & $\begin{array}{c}10.4 \\
2\end{array}$ & 0 & 4 \\
\hline 35 & 96 & 12 & 10.44 & $\begin{array}{c}10.4 \\
4 \\
\end{array}$ & 91 & 5 & $\begin{array}{c}10.4 \\
9 \\
\end{array}$ & 0 & 5 \\
\hline 36 & 75 & 10 & 10.47 & $\begin{array}{c}10.4 \\
9\end{array}$ & 99 & 5 & $\begin{array}{c}10.5 \\
4\end{array}$ & 2 & 7 \\
\hline 37 & 18 & 4 & 10.50 & $\begin{array}{c}10.5 \\
4\end{array}$ & 3 & 2 & $\begin{array}{c}10.5 \\
6\end{array}$ & 4 & 6 \\
\hline 38 & 49 & 7 & 10.55 & $\begin{array}{c}10.5 \\
6 \\
\end{array}$ & 55 & 4 & $\begin{array}{c}11.0 \\
0 \\
\end{array}$ & 1 & 5 \\
\hline 39 & 76 & 10 & 11.59 & $\begin{array}{c}11.0 \\
0\end{array}$ & 31 & 3 & $\begin{array}{c}11.0 \\
3\end{array}$ & 1 & 4 \\
\hline 40 & 35 & 6 & 11.03 & $\begin{array}{c}11.0 \\
3\end{array}$ & 19 & 2 & $\begin{array}{c}11.0 \\
5\end{array}$ & 0 & 2 \\
\hline 41 & 38 & 6 & 11.12 & $\begin{array}{c}11.1 \\
2 \\
\end{array}$ & 63 & 4 & $\begin{array}{c}11.1 \\
6 \\
\end{array}$ & 0 & 4 \\
\hline 42 & 89 & 11 & 11.15 & $\begin{array}{c}11.1 \\
6 \\
\end{array}$ & 35 & 3 & $\begin{array}{c}11.1 \\
9 \\
\end{array}$ & 1 & 4 \\
\hline 43 & 56 & 8 & 11.18 & $\begin{array}{c}11.1 \\
9 \\
\end{array}$ & 71 & 4 & $\begin{array}{c}11.2 \\
3 \\
\end{array}$ & 1 & 5 \\
\hline 44 & 95 & 12 & 11.21 & $\begin{array}{c}11.2 \\
3 \\
\end{array}$ & 39 & 3 & $\begin{array}{c}11.2 \\
6 \\
\end{array}$ & 2 & 5 \\
\hline 45 & 58 & 8 & 11.25 & $\begin{array}{c}11.2 \\
6 \\
\end{array}$ & 23 & 2 & $\begin{array}{c}11.2 \\
8 \\
\end{array}$ & 1 & 3 \\
\hline 46 & 29 & 5 & 11.33 & $\begin{array}{c}11.3 \\
3\end{array}$ & 15 & 2 & $\begin{array}{c}11.3 \\
5\end{array}$ & 0 & 2 \\
\hline 47 & 36 & 6 & 11.39 & $\begin{array}{c}11.3 \\
9\end{array}$ & 11 & 2 & $\begin{array}{c}11.4 \\
1\end{array}$ & 0 & 2 \\
\hline 48 & 55 & 8 & 11.42 & $\begin{array}{c}11.4 \\
2 \\
\end{array}$ & 59 & 4 & $\begin{array}{c}11.4 \\
6 \\
\end{array}$ & 0 & 4 \\
\hline 49 & 78 & 10 & 11.48 & $\begin{array}{c}11.4 \\
8 \\
\end{array}$ & 83 & 5 & $\begin{array}{c}11.5 \\
3 \\
\end{array}$ & 0 & 5 \\
\hline
\end{tabular}




\begin{tabular}{|c|c|c|c|c|c|c|c|c|c|}
\hline$\frac{0}{0}$ & $\mathrm{RN}$ & IAT & AT & SST & $\mathrm{RN}$ & $\begin{array}{l}\mathrm{S} \\
\mathrm{T}\end{array}$ & SET & $\begin{array}{l}\text { TI } \\
\mathrm{Q}\end{array}$ & $\begin{array}{l}\mathrm{TI} \\
\mathrm{S}\end{array}$ \\
\hline 50 & 69 & 9 & 11.52 & $\begin{array}{c}11.5 \\
3\end{array}$ & 95 & 5 & $\begin{array}{c}11.5 \\
8\end{array}$ & 1 & 6 \\
\hline 51 & 16 & 4 & 11.57 & $\begin{array}{c}11.5 \\
8\end{array}$ & 51 & 4 & $\begin{array}{c}12.0 \\
2\end{array}$ & 1 & 5 \\
\hline 52 & 15 & 4 & 12.00 & $\begin{array}{c}12.0 \\
2\end{array}$ & 79 & 5 & $\begin{array}{c}12.0 \\
7\end{array}$ & 2 & 7 \\
\hline 53 & 98 & 12 & 12.12 & $\begin{array}{c}12.1 \\
2\end{array}$ & 43 & 3 & $\begin{array}{c}12.1 \\
5\end{array}$ & 0 & 3 \\
\hline 54 & 9 & 3 & 13.00 & $\begin{array}{c}13.0 \\
0 \\
\end{array}$ & 75 & 4 & $\begin{array}{c}13.0 \\
4 \\
\end{array}$ & 0 & 4 \\
\hline 55 & 96 & 12 & 13.03 & $\begin{array}{c}13.0 \\
4\end{array}$ & 91 & 5 & $\begin{array}{c}13.0 \\
9\end{array}$ & 1 & 6 \\
\hline 56 & 75 & 10 & 13.10 & $\begin{array}{c}13.1 \\
0\end{array}$ & 99 & 5 & $\begin{array}{c}13.1 \\
5\end{array}$ & 0 & 5 \\
\hline 57 & 18 & 4 & 13.17 & $\begin{array}{c}13.1 \\
7 \\
\end{array}$ & 3 & 2 & $\begin{array}{c}13.1 \\
9 \\
\end{array}$ & 0 & 2 \\
\hline 58 & 49 & 7 & 13.24 & $\begin{array}{c}13.2 \\
4\end{array}$ & 55 & 4 & $\begin{array}{c}13.2 \\
8\end{array}$ & 0 & 4 \\
\hline 59 & 76 & 10 & 13.32 & $\begin{array}{c}13.3 \\
2\end{array}$ & 31 & 3 & $\begin{array}{c}13.3 \\
5\end{array}$ & 0 & 3 \\
\hline 60 & 35 & 6 & 13.36 & $\begin{array}{c}13.3 \\
6\end{array}$ & 19 & 2 & $\begin{array}{c}13.3 \\
8\end{array}$ & 0 & 2 \\
\hline 61 & 38 & 6 & 13.41 & $\begin{array}{c}13.4 \\
1 \\
\end{array}$ & 63 & 4 & $\begin{array}{c}13.4 \\
5 \\
\end{array}$ & 0 & 4 \\
\hline 62 & 89 & 11 & 13.45 & $\begin{array}{c}13.4 \\
5\end{array}$ & 35 & 3 & $\begin{array}{c}13.4 \\
8\end{array}$ & 0 & 3 \\
\hline 63 & 56 & 8 & 13.50 & $\begin{array}{c}13.5 \\
0\end{array}$ & 71 & 4 & $\begin{array}{c}13.5 \\
4\end{array}$ & 0 & 4 \\
\hline 64 & 95 & 12 & 13.59 & $\begin{array}{c}13.5 \\
9\end{array}$ & 39 & 3 & $\begin{array}{c}14.0 \\
2 \\
\end{array}$ & 0 & 3 \\
\hline 65 & 58 & 8 & 14.03 & $\begin{array}{c}14.0 \\
3\end{array}$ & 23 & 2 & $\begin{array}{c}14.0 \\
5\end{array}$ & 0 & 2 \\
\hline 66 & 29 & 5 & 14.08 & $\begin{array}{c}14.0 \\
8\end{array}$ & 15 & 2 & $\begin{array}{c}14.1 \\
0\end{array}$ & 0 & 2 \\
\hline 67 & 36 & 6 & 14.12 & $\begin{array}{c}14.1 \\
2\end{array}$ & 11 & 2 & $\begin{array}{c}14.1 \\
4\end{array}$ & 0 & 2 \\
\hline 68 & 55 & 8 & 14.16 & $\begin{array}{c}14.1 \\
6\end{array}$ & 59 & 4 & $\begin{array}{c}14.2 \\
0\end{array}$ & 0 & 4 \\
\hline 69 & 78 & 10 & 14.20 & $\begin{array}{c}14.2 \\
0\end{array}$ & 83 & 5 & $\begin{array}{c}14.2 \\
5\end{array}$ & 0 & 5 \\
\hline 70 & 69 & 9 & 14.26 & $\begin{array}{c}14.2 \\
6\end{array}$ & 95 & 5 & $\begin{array}{c}14.3 \\
1\end{array}$ & 0 & 5 \\
\hline 71 & 16 & 4 & 14.31 & $\begin{array}{c}14.3 \\
1\end{array}$ & 51 & 4 & $\begin{array}{c}14.3 \\
5\end{array}$ & 0 & 4 \\
\hline 72 & 15 & 4 & 14.36 & $\begin{array}{c}14.3 \\
6\end{array}$ & 79 & 5 & $\begin{array}{c}14.4 \\
1\end{array}$ & 0 & 5 \\
\hline 73 & 98 & 12 & 14.41 & $\begin{array}{c}14.4 \\
1\end{array}$ & 43 & 3 & $\begin{array}{c}14.4 \\
4\end{array}$ & 0 & 3 \\
\hline 74 & 9 & 3 & 14.46 & $\begin{array}{c}14.4 \\
6 \\
\end{array}$ & 75 & 4 & $\begin{array}{c}14.5 \\
0 \\
\end{array}$ & 0 & 4 \\
\hline 75 & 96 & 12 & 14.50 & $\begin{array}{c}14.5 \\
0\end{array}$ & 91 & 5 & $\begin{array}{c}14.5 \\
5\end{array}$ & 0 & 5 \\
\hline 76 & 75 & 10 & 14.55 & $\begin{array}{c}14.5 \\
5\end{array}$ & 99 & 5 & $\begin{array}{c}15.0 \\
0\end{array}$ & 0 & 5 \\
\hline 77 & 18 & 4 & 14.59 & $\begin{array}{c}15.0 \\
0\end{array}$ & 3 & 2 & $\begin{array}{c}15.0 \\
2\end{array}$ & 1 & 3 \\
\hline 78 & 49 & 7 & 15.05 & $\begin{array}{c}15.0 \\
5\end{array}$ & 55 & 4 & $\begin{array}{c}15.0 \\
9\end{array}$ & 0 & 4 \\
\hline 79 & 76 & 10 & 15.10 & $\begin{array}{c}15.1 \\
0\end{array}$ & 31 & 3 & $\begin{array}{c}15.1 \\
3\end{array}$ & 0 & 3 \\
\hline 80 & 35 & 6 & 15.13 & $\begin{array}{c}15.1 \\
3\end{array}$ & 19 & 2 & $\begin{array}{c}15.1 \\
5\end{array}$ & 0 & 2 \\
\hline \multicolumn{8}{|c|}{ JUMLAH } & 39 & $\begin{array}{c}31 \\
9\end{array}$ \\
\hline
\end{tabular}

\begin{tabular}{|c|c|c|c|c|c|c|c|c|c|}
\hline$\frac{\ddots}{30}$ & RN & IAT & AT & SST & $\mathrm{RN}$ & $\begin{array}{l}\mathrm{S} \\
\mathrm{T}\end{array}$ & SET & $\begin{array}{l}\text { TI } \\
\mathrm{Q}\end{array}$ & $\begin{array}{l}\text { TI } \\
\text { S }\end{array}$ \\
\hline & & & RAT & ATA & & & & 0.5 & $\begin{array}{l}4 . \\
0\end{array}$ \\
\hline
\end{tabular}

Keterangan :

a. RN: Random Number (Bilangan Acak)

b. IAT : Inter-Arrival Time (Selisih waktu kedatangan)

c. AT : Arrival Time (waktu kedatangan)

d. SST : Service Start Time (mulai dilayani)

e. ST : Service time (waktu pelayanan)

f. SET : Service End Time (selesai dilayani)

g. TIQ antrian)

h. TIS

: Time In Queue (waktu dalam sistem)

Hasil dari pengolahan data menggunakan model antrian dengan menggunakan metode monte carlo dapat dilihat pada tabel 3.10 berikut:

Tabel 3.10 Informasi Fase Pelayanan Pengambilan Obat

\begin{tabular}{|c|c|c|l|}
\hline \multirow{4}{*}{ Infor } & $\begin{array}{c}\text { Rata-rata waktu } \\
\text { menunggu pasien }\end{array}$ & $\begin{array}{c}39 / 80 \\
=0,50\end{array}$ & Menit \\
\cline { 2 - 4 } masi & diantrian & $319 /$ & \\
& Rata-rata waktu pasien & $80=$ & Menit \\
& disistem & 4,00 & \\
\hline
\end{tabular}

\section{IMPLEMENTASI DAN PENGUJIAN}

\section{A. Implementasi Sistem}

Implementasi memiliki tujuan untuk menentukan dan memastikan apakah hasil analisa tersebut telah sesuai dengan keputusan yang diharapkan.

\section{B. Pengujian Sistem Informasi}

Tahapan pengujian merupakan tahapan yang dilakukan untuk memastikan apakah sistem yang sudah dirancang dan dibangun sudah dapat berjalan sesuai dengan yang diharapkan.

\subsubsection{Pengujian Interface}

Pengujian dan Implementasi sistem bertujuan untuk melihat apakah sistem yang dirancang sudah sesuai dengan apa yang diinginkan atau belum.

Berikut ini adalah implementasi dari perancangan aplikasi yang dibangun.

1. Halaman Login

Halaman pertama yang akan tampil ketika user akan masuk kedalam sistem. Tampilan dari halaman login ini dapat dilihat pada gambar berikut ini: 


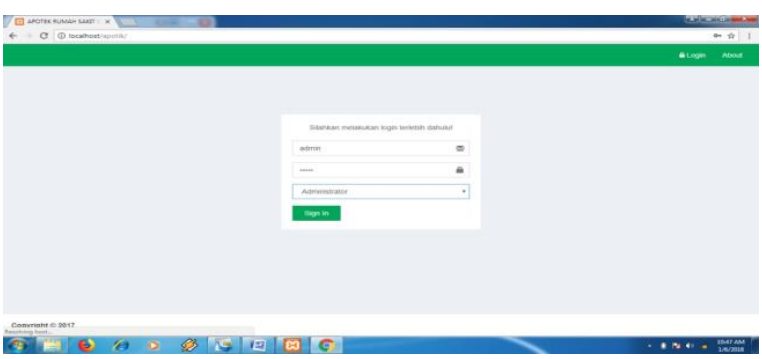

Gambar 4.1 Tampilan Halaman Login

\section{Halaman Home}

Merupakan halaman pertama yang akan diakses oleh sistem setelah aktor berhasil melakukan proses login. Dapat dilihat pada gambar berikut:

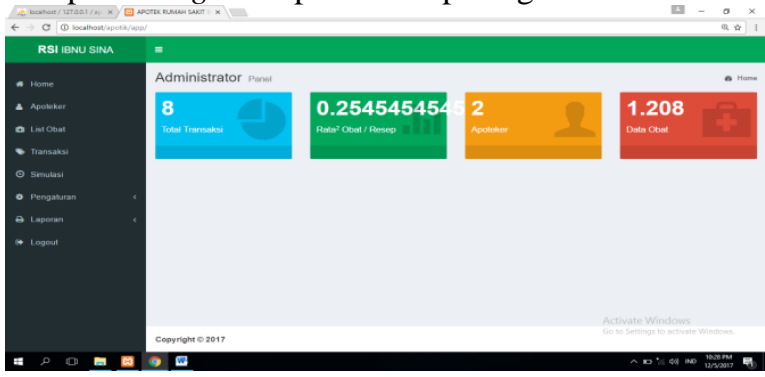

Gambar 4.2 Tampilan Halaman Home Admin

3. Halaman Input Data Antrian

Untuk melakukan sistem antrian menggunakan metode Monte Carlo, sebelumnya apoteker menginput kan data antrian. Dapat dilihat pada gambar berikut ini:

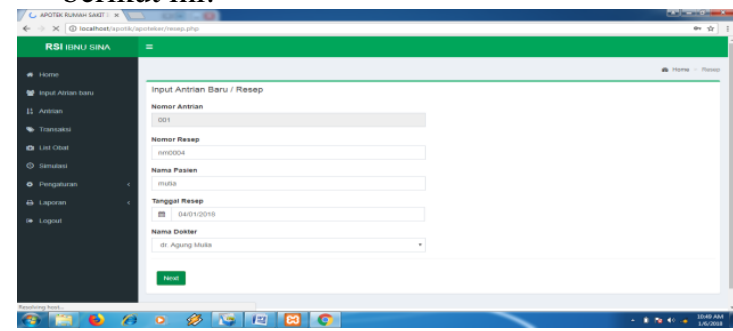

Gambar 4.3 Tampilan Halaman Input Data Antrian

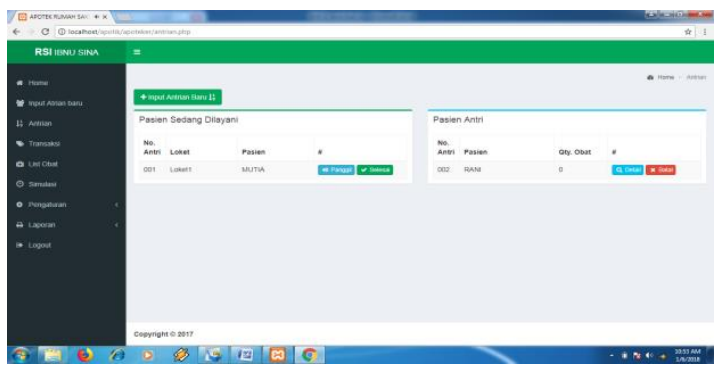

Gambar 4.4 Tampilan Halaman Data Antrian

4. Halaman Simulasi

Merupakan daftar-daftar data simulasi yang terdata pada sistem. Dapat dilihat pada gambar berikut:

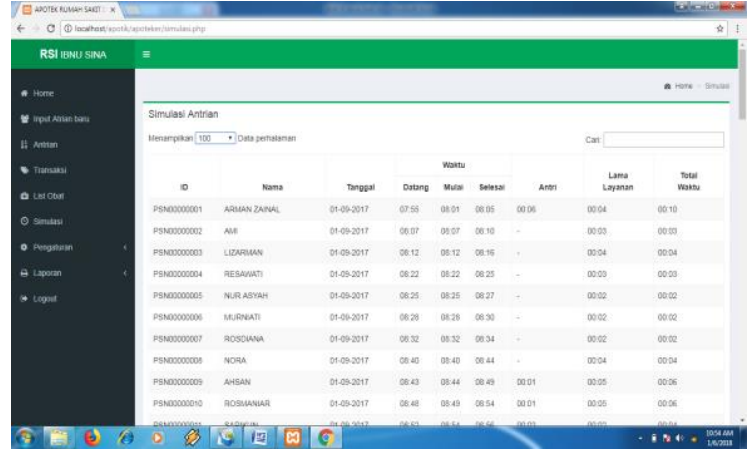

Gambar 4.5 Halaman Simulasi

\section{PENUTUP}

\section{A. Kesimpulan}

Berdasarkan dari proses pembuatan simulasi antrian yang telah dilakukan oleh penulis, maka penulis membuat kesimpulan bahwa :

1. Teori antrian dapat digunakan untuk memecahkan suatu masalah dalam suatu fasilitas pelayanan, dengan ini dapat diperoleh suatu model antrian yang dapat digunakan untuk mengetahui apakah suatu fasilitas sudah bekerja secara optimal sehingga pelayanan di loket pengambilan obat RSI. Ibnu Sina Pasaman Barat berjalan dengan efektif dan efisien.

2. Dengan menggunakan metode Monte Carlo antrian yang pada awalnya panjang menjadi berkurang, dapat meringankan pihak RSI. Ibnu Sina Pasaman Barat dan pasien jadi lebih tau berapa lama waktu untuk mengantri.

3. Dengan digantinya sistem antrian di loket pengambilan obat RSI. Ibnu Sina Pasaman Barat dapat mengurangi penumpukan antrian yang terjadi sehingga pelayanan menjadi efisien.

\section{B. Saran}

Berdasarkan penelitian yang telah dilakukan penulis memberikan saran yang dapat dilakukan diantaranya yaitu :

1. Dari kajian diatas, penulis mengharapkan adanya penelitian lanjutan, karena ada beberapa bagian yang tidak di bahas, karena keterbatasan waktu dan batasan dari permasalahan yang telah ditetapkan sebelumnya.

2. Sebelum menerapkan suatu kejadian antrian kedalam keadaan nyata ada baiknya lakukan dulu analisis dan perbandingan terhadap model antrian yang akan diterapkan dengan begitu akan mendapatkan model antrian yang cocok untuk aplikasikan.

3. Data antrian yang sudah diinputkan dalam pemanggilan antriannya di panggil berdasarkan nomor antrian yang telah disediakan belum berdasakan nama pasien yang ddiinputkan. 


\section{DAFTAR PUSTAKA}

[1] Ramadhan, Fadillah, dkk, 2014. Pemodelan dan Simulasi Berbasis Agen untuk Sistem Industri Kuliner. Jurnal Online Institut Teknologi Nasional. Vol. 01. No. 03. ISSN : 2338-5081

[2] Susanti, Ida, dkk. 2015. Analisis Perbaikan Sistem Antrian Pelanggan Skin Care XYZ Dengan Menggunakan Model Simulasi. Seminar Nasional IENACO. ISSN : 2337-4349.

[3] Arwindy, Faradhika, dkk. 2014. Analisis dan Simulasi Sistem Antrian Pada Bank ABC. Saintia Matematika. Vol. 2. No. 2.

[4] Sembiring, Alpianus. 2015. Perancangan Simulasi Penjualan Barang Dengan Metode Monte Carlo (Studi Kasus : Koperasi Karyawan Tenera Unit Sei Kopas). Pelita Informatika Budi Darma. Vol. IX, No : 3, ISSN : 2301-9425.

[5] Ayu, Raja Mahesa, dkk. 2017. Pemodelan Dan Simulasi Sistem Antrian Pelayanan Pelanggan Menggunakan Metode Monte Carlo Pada PT Pos Indonesia (Persero) Padang. Jurnal Ilmu Komputer. ISSN : 2579-3918. 